\title{
УДК 165.731:37.09 (410) «19»(043.5)
}

ТРӦ̈ЦЬКА Олена - доктор філософських наук, професор кафедри філософії, Мелітопольський державний педагогічний університет імені Богдана Хмельницького, 20, вул. Гетьманська, м. Мелітополь, Запорізька обл., Україна, індекс72300 (troizka2015@ukr.net)

ORCID: https://orcid.org/0000-0003-4330-084X

ПЕШЕВ Олег - кандидат філософських наук, старший викладач кафедри філософії, Мелітопольський державний педагогічний університет імені Богдана Хмельницького, 20, вул. Гетьманська, м. Мелітополь, Запорізька обл., Украӥна, індекс 72300 (peshev1988@gmail.com)

ORCID: https://orcid.org/0000-0001-8776-9602

DOI: https://doi.org/10.24919/2522-4700.42.19

Бібліографічний опис статті: Троїцька, О., Псшев, О. (2021). Британська аналітична філософія освіти Р. Пітерса в українських контекстах. Людинознавчі студіі: збірник наукових прачь Дрогобищького державного педагогічного університету імені Івана Франка. Серія «Філософія», 42, 292-303, doi: https://doi.org/10.24919/2522-4700.42.19

\section{БРИТАНСЬКА АНАЛІТИЧНА ФІЛОСОФІЯ ОСВІТИ Р. ПІТЕРСА В УКРАЇНСЫКИХ КОНТЕКСТАХ}

Анотація. Метою статті є виявлення взаємозв'язків між британською аналітичною філософією освіти та украӥнськими освітніми засадами. Активна взаємодія вітчизняної філософії освіти із сочіально-педагогічними ідеями та досвідом краӥн Західної Свропи виявилася значущим чинником залучення України до процесу сочіально-педагогічного генезису, що зумовлює ї̈ сучасний розвиток. Методологічними засадами дослідження стали позитивізм, аналітична філософія освіти та педагогіка.

Аналітична філософія освіти розглядається як система знань, щуо являє собою не просто об'єм, блок знань про ту чи іншу сферу дійсності, але й формою впорядкування, організаиіі вже раніше отриманих знань, формою співпращі $і$ комунікащіі учених у всьому світі.

Наукова новизна. Зосереджуючи увагу на аспекті взаємодї філософії освіти України з ідеями філософії освіти

(C) Троїцька Олена, Пєшев Олег, 2021 
Великобританії, робимо акиент на діяльнісному компоненті філософії, який знаходить своє вираження у визначенні форм освітньої організації, пошуку оптимальних комунікаційних каналів, щуо визначають становлення знань та освіченості.

Висновки. Визначення пріоритетів освітньої політики на користь самореалізації особистості учня й формування творчого характеру цього розвитку не лише сприяло подоланню одноманітності колишньої уніфікованої школи, але й зумовило появу численних нових освітніх технологій. У иььому контексті вивчення філософської спадщчини англійського філософа освіти Р.С. Пітерса, щуо створив оригінальну аналітичну конщепцію, засновану на синтезі філософських, громадянських та психолого-педагогічних ідей свого часу, скеровану насамперед на вирішення питань соціального виховання й розвитку громадянина, є теоретично й практично затребуваним завданням.

Успішність реалізації розробленої Р.С. Пітерсом педагогічної концепиії $і$ широта ї̈ застосування у вітчизняній педагогічній практиці можливі за умови підготовки педагогів нового типу, щзо володіють спеціальною компетенцісю $і$ засвоїли аналітичний підхід мислителя на вітчизняній мовній і світоглядній базі.

Ключові слова: філософія освіти, концепція, аналітична філософія, лібералізація, позитивізм, філософія мови.

TROITSKA Olena - Doctor of Philosophy, Professor at the Philosophy Department, Bogdan Khmelnitsky Melitopol State Pedagogical University, 20, Hetmanska str., Melitopol, Zaporizhia region, Ukraine, postal code 72300 (troizka2015@ukr.net)

ORCID: https://orcid.org/0000-0003-4330-084X

PIESHEV Oleg - Candidate of Philosophical Sciences, Senior Lecturer at the Philosophy Department, Bogdan Khmelnitsky Melitopol State Pedagogical University, 20, Hetmanska str., Melitopol, Zaporizhia region, Ukraine, postal code 72300 (peshev1988@gmail.com)

ORCID: https://orcid.org/0000-0001-8776-9602

DOI: https://doi.org/10.24919/2522-4700.42.19

To cite this article: Troitska, O., Pieshev, O. (2021). Brytanska analitychna filosofiia osvity R. Pitersa v ukrainskykh kontekstakh [R. Peters' British analytical philosophy of education in Ukrainian contexts]. Liudynoznavchi studii: zbirnyk naukovykh prats Drohobytskoho derzhavnoho pedahohichnoho universytetu imeni Ivana Franka. Seriia "Filosofiia" - 
Human Studies. Series of "Philosophy": a collection of scientific articles of the Drohobych Ivan Franko State Pedagogical University, 42, 292-303, doi: https://doi.org/10.24919/2522-4700.42.19

\section{R. PETERS' BRITISH ANALYTICAL PHILOSOPHY OF EDUCATION IN UKRAINIAN CONTEXTS}

Summary. The purpose of the article is to identify the relationship between the British analytical philosophy of education and Ukrainian educational principles. The active interaction of the national philosophy of education with the socio-pedagogical ideas and experience of Western Europe was a significant factor in Ukraine's involvement in the process of socio-pedagogical genesis, which determines its modern development. Methodological foundations of the study are positivism, analytical philosophy of education and pedagogy. Analytical philosophy of education is considered as a system of knowledge, which is "not just a volume, a block of knowledge about a particular area of reality", but also considered as "a form of ordering, organization of already acquired knowledge, form of cooperation and communication of scientists".

Scientific novelty. Focusing on the aspect of interaction of the philosophy of education of Ukraine with the ideas of the philosophy of education of Great Britain, the emphasis is on the activity component of philosophy, which finds its expression in determining the forms of educational organization, finding optimal communication channels that determine knowledge and education.

Conclusions. Determining the priorities of educational policy in favor of self-realization of the student's personality and the formation of the creative nature of this development not only helped to overcome the monotony of the former unified school, but also led to the emergence of numerous new educational technologies. In this context, the study of the philosophical heritage of the English philosopher of education $R S$ Peters, who created an original analytical concept based on the synthesis of philosophical, civic and psychological-pedagogical ideas of his time, and aimed primarily at solving problems of social education and development of the citizen, is theoretically and practically a popular task.

The success of the implementation of the developed R.S. Peters pedagogical concept and the breadth of its application in domestic 
pedagogical practice is possible provided the training of teachers of a new type with special competence and mastered the analytical approach of the thinker on the domestic language and worldview.

Key words: philosophy of education, concept, analytical philosophy, liberalization, positivism, philosophy of language.

Постановка проблеми. Спадковість та інтеграція досвіду застосування педагогічної спадщини Р.С. Пітерса в європейських країнах є підставою для практичної реалізації педагогічної моделі, що відповідає сучасним завданням виховання українського громадянина. Проте досягнення цієї мети можливе лише за умови застосування зваженого, осмисленого впровадження пітерсівської концепції, що має спиратись на національну ментальність і культурно-історичну спадковість разом із розумінням сучасних рівнів різних галузей суспільствознавства. Освіта за такого підходу стає діяльною єдністю людини й соціокультурного середовища, які взаємно проникають одне в одне, що стимулює інтерес до розвитку, нових шляхів творчості й самореалізації.

Метою статті $\epsilon$ виявлення взаємозв'язків між британською аналітичною філософією освіти та українськими освітніми засадами. Активна взаємодія вітчизняної філософії освіти із соціально-педагогічними ідеями та досвідом країн Західної Європи виявиласязначущимчинникомзалучення Українидопроцесусоціально-педагогічного генезису, що зумовлює її сучасний розвиток.

Аналіз останніх досліджень і публікацій. Найзагальніші положення, що об'єднують різні вітчизняні освітні концепції, базуються на входженні особистості у світ «життєвих сенсів» та актуалізуються в сучасних філософсько-педагогічних дослідженнях, пов'язаних передусім із детермінантами освітньої діяльності, що досліджується в працях В. Андрущенка, I. Беха, М. Бойченка, I. Волощука, Л. Губерського, С. Клепко, Н. Кочубей, В. Кременя, В. Молодиченка, Г. Фініна та інших науковців.

Основний матеріал. Створена філософом концепція освіти була обумовлена історичною ситуацією того часу, схожою за своєю проблематикою із ситуацією нашого часу. Затребуваність соціально-педагогічних ідей Р.С. Пітерса пов' язана також із тим, що його творчість була спрямована на наукове обгрунтування 
формуючої функції знання й ціннісної структури освіти, лібералізації освіти, критики авторитарності виховання, водночас на протест проти відверто індивідуалістичних тенденцій.

Досі не втрачає цінності розуміння мислителем освіченої людини як суб' єкта, який працює з точністю, пристрастю і має потяг до інтелектуально цінних речей (Peters, 1972, p. 10). Він не $\epsilon$ вузькоспеціалізованим або тим, хто бачить навчання як інструмент для досягнення інших соціальних благ, таких як багатство, статус і влада. Хоча освіта $є$ нормативною, вона прямо стосується розвитку індивіда, а також має нормативні, культурні та соціальні аспекти. Р.С. Пітерс підкреслює, що освіта $є$ «формою посвячення в сенс діяльності». Її можна розглядати як форму передачі культурних цінностей, таких як соціальна справедливість, рівність можливостей, повага до людей.

Сучасний акцент на інтеграційних, адаптаційних, а також соціокультурних особливостях освіти не зменшує інтерес учених до розуміння стану «освіченості». Як і раніше, визнається цінність традиційних академічних предметів, таких як література, мистецтво, філософія. Такі сучасні західні філософи освіти, як Р. Глас, М. Епл, П. Макларен, П. Фрейре, переконують студентів зробити те, що Р.С. Пітерс, на їхню думку, не позначив у своїй концепції освіти, а саме аналізувати процес обміну своїми культурами й звертати увагу на те, як ці культури маргіналізують одних і пригнічують інших (Glass, 2000, p. 275).

I. Радіонова зазначає при цьому, що П. Макларен вказує на те, що студенти та учні, що є представниками успішних верств населення, схильні до конформної поведінки і сприймають пропоноване критичною педагогікою ставлення до суспільства й соціальної справедливості як загрозу їхнім ідеологічним переконанням (Radionova, 2013, p. 196).

Аналітична філософія освіти Р.С. Пітерса спонукає кожне нове покоління переосмислити цілі освіти. Вони мають бути переглянуті через призму сучасних політичних, соціальних та економічних умов. Лише так стає можливим позначити змістовну сутність, яку можна віднести до ідеалу загальної освіти. У цьому разі перед людьми відкривається те, що цілі освіти не $€$ принципово визначеними й повинні позначатися відповідно до кожного конкретного історичного періоду. Р.С. Пітерс мав це на 
увазі, коли цитував Дж. Дьюї: «Утвердження мети є предметом турботи в даний момент часу» (Djjui, 2000, p. 20).

Цілі освіти для Р. Пітерса апріорі не визначені. Така невизначеність може бути досить корисною, а саме для нагадування політикам і педагогам про те, що неможливо уникнути критичного діалогу щодо цілей і змісту освіти. Такий діалог дуже важливий сьогодні, оскільки культурні реалії, з якими ми стикаємося, вимагають постановки нових цілей і завдань.

Система освіти, яка була створена у XX ст., щоб адаптувати людину до індустріалізації та урбанізації, з кожним роком набуває нових рис та особливостей (Glass, 2000, p. 262). Така система спрямована здебільшого на реалізацію того, з чим вона успішно справлялася в минулому столітті, а саме на соціалізацію студентів через навчання для їх подальшого сортування згідно 3 навчальним досягненням й визначення в осередку соціуму. Ці функції мають мало спільного з вихованням, про яке говорить P.С. Пітерс. На його думку, багато педагогів і політиків розглядають освіту як формальне навчання, як засіб, за допомогою якого здійснюється постачання трудових ресурсів (Peters, 1968, p. 27).

Очевидно, що світ, який успадкує нове покоління, буде відрізнятися від того, в якому жив Р.С. Пітерс, коли писав свої ранні праці. Це буде світ, у якому людина стикається з величезною кількістю інформації і має занадто мало часу, щоб їі обробляти та ефективно використовувати. Це світ, де виховання все ще може перешкоджати усвідомленому політичному рішенню, світ, де відмінність між багатими й бідними може стати загрозою економічному благополуччю багатьох соціальних груп (Katz, 1996, p. 123).

Як зазначає М. Култаєва, долю України сьогодні визначають покоління, що були народженні у часи їі незалежності. Саме від їх людських якостей, стратегію формування яких визначає філософія освіти, буде залежати майбутнє української нації. Однак для того, щоби перейти від романтичного сп'яніння свободою до раціональних практик іiі застосування задля забезпечення стійкого розвитку усіх сфер суспільного життя, треба цілеспрямовано, тобто засобами освіти й виховання, формувати культуру свободи, котра базується на демократичних принципах і цінностях (Kultajeva, 2014, p. 188). 
I. Предборська вказує на те, що у сучасній системі освіти спостерігається процес штучного розриву навчання й виховання, однак зміна цивілізаційного імперативу сама по собі актуалізує проблеми виховання. Вона також зазначає, що сучасна освіта повинна слугувати свого роду компасом, який буде допомагати особистості у пошуку свого місця у світі (Predborsjka, 2003, p. 38-39).

Це повертає нас до важливості усвідомлення «концепції освіти», як це робив Р.С. Пітерс. Слід зауважити, що сучасні філософи освіти повинні знайти нову концептуальну основу й позначити іiї логічні точки.

Припустимо, що освіта включає розвиток знання й розуміння. Існує досить дивна аномалія: $є$ дуже багато праць про знання, але дуже мало про розуміння. Освіта передбачає також певне навчання. Однак існує дуже мало праць щодо концепту «навчання» і ще менше стосовно такої діяльності, як викладацька. Саме вона сприяє навчанню (Peters, 1972, p. 111).

Погляди Л. Губерського співзвучні пітерсівському баченню вищої освіти, адже саме слово «університет» етимологічно означає «загальність, усебічність». Найбільш чітко ідею місії університету відображає закладене в основу Гумбольдтського університету німецьке слово Bildung, яке в перекладі має подвійне значення: і освіту як отримання знань, і освіту як творення людини. (Ghubernskij, 2012, p. 6).

Розуміння освіти як цінності $є$ актуальним. Академік В. Андрущенко влучно зазначає таке.

«Освіта має формувати людину як патріота і громадянина. Повага до народів світу стане осмисленою цінністю лише тоді, коли спирається на повагу до власного народу, власної культурно-історичної традиції, батьківських духовних цінностей, мови» (Andrushenko, 2010, p. 88).

Філософ вважає, що в основу національного виховання мають бути покладені принципи гуманізму, демократизму, культурної відповідальності, толерантності, спадковості поколінь.

М. Міщенко зазначає, що реформування освіти, створення новітніх, модерних освітніх програм - це головна умова для України стати на один рівень із західними країнами, бути для них рівноправним співучасником творення світової історії 
та розбудови майбутнього людської цивілізації. Однак при цьому важливо не лише забезпечувати освітній процес, але й приділяти увагу його внутрішній наповненості. Українська освіта, на відміну від західноєвропейських країн, не є вузькоспеціалізованою, технологічною та утилітарною. Вона схильна до світоглядних та гуманітарних аспектів. Українське суспільство мусить мати систему ціннісних орієнтацій, чітких ідеологічних координат, ключовим ядром яких є українська національна ідея. Як і Р.С. Пітерс, М. Міщенко вказує на те, що загальнолюдські цінності мають постійний характер і є зразком поведінки для всіх людей (Mishenko, 2015, p. 279).

Про важливість цінностей у сучасному освітньому та виховному процесі говорить М. Бойченко. На його думку, сьогоднішня криза культури пов'язана з утратою гуманістичних моральних цінностей: «Цінності <..> є тією категорією, без якої неможливо уявити побудову теорії як особистості, так і соціальних систем» (Bojchenko, 2009, p. 102).

В. Молодиченко вказує на те, що освіта $є$ найважливішим інституційним каналом відтворення духовних цінностей, тому явні й приховані цільові установки освітньої системи визначають ступінь поширення духовних цінностей у соціумі, чим впливають на його ціннісну інтегрованість у культурну гомогенність (Molodychenko, 2010, p. 384).

Таким чином, тісний взаємозв'язок цінностей і процесу формування ціннісних орієнтацій з освітніми практиками є однією 3 найважливіших характеристик взаємозумовлення освіти та духовних цінностей.

Говорячи про цінності, В. Кремень зазначає, що дуже важливо, щоби була визначена аксіологічна спрямованість навчально-виховного процесу, при цьому важливо враховувати як реалії сьогодення, так і перспективи.

Саме враховуючи ці чинники в межах розмаїття ціннісних орієнтацій, що можуть застосовуватись у процесі навчання, маємо визначити пріоритетні цінності. Такими для України історично були й залишаються цінності гуманізму, людської гідності, патріотизму, демократизму, соціальної ініціативи та відповідальності, національної самосвідомості з ії центром - національною ідеєю (Kremenj, 2014, p. 435). 
Аналогічно до Р.С. Пітерса, В. Кремень вказує на те, що необхідність філософії освіти зумовлена статусом освіти вчити і виховувати (у їх безперервній взаємодії). Мета будь-якої освітньої системи полягає у формуванні такого практичного світогляду людини, який би краще поєднував професійну діяльність із загальними цивілізаційними цінностями, закладеними в основу цієї системи (Kremenj, 2014, p. 472).

С. Клепко підтверджує думку Р.С. Пітерса щодо інтегративної освіти й говорить про те, що сучасна освіта $є$ «стрічкою» текстів, які засвоює учень. Незважаючи на стандартизацію навчального процесу, такі «стрічки» залишаються досить різними, особливо на завершальних стадіях освіти, коли внаслідок професійної спрямованості, вузької спеціалізації вищої освіти в умовах сучасної економіки багато людей стають заручниками своєї освіти (Klepko, 2006, p. 121).

Р. Пітерс неодноразово говорить про важливість формування високого рівня компетентності і професійної майстерності особистості, що дає змогу віднести ці аспекти до акмеологічних. Як відомо, акмеологічний підхід у системі професійної освіти полягає в тому, щоб забезпечити посилення професійної мотивації, стимулювати творчий потенціал, а також використовувати особистісні ресурси для досягнення успіхів у педагогічній діяльності. Проблема компетентісної освіти досить тісно пов'язана зі змінами, що відбуваються у суспільстві. Таким чином, навчальний заклад мусить формувати у своїх студентів такі якості, як динамізм, ініціатива, конструктивізм, творчість, самостійність.

Розвиток освіти є стратегічним ресурсом подолання кризових процесів, основним засобом розвитку гуманістичної сутності людини. Суспільна потреба в освічених людях актуалізує такі функції, як економічна та соціальна. На етапі утвердження України як правової держави постає проблема відставання від світових тенденцій економічного й соціального розвитку. У цьому контексті надзвичайно актуальним є піднесення освіти до основних державних пріоритетів. Водночас для формування та реалізації якісної освітньої політики варто визначити принципи, на яких базується державна політика у галузі освіти.

Висновки. Розроблення концепції модернізації вітчизняної системи освіти та іiі змісту стає актуальним завданням. 
У Національній доктрині розвитку освіти України окреслені тривалі пріоритети освіти та визначені шляхи ії трансформації, де першорядного значення набуває освіта саме як чинник розвитку особистості. Проте освітянська практика доводить, що заплановані реформи або є недостатньо дієвими, або неповною мірою втілюються в життя, оскільки їх вплив на ефективність освітньої сфери принципово недостатній. В. Кремень справедливо зазначив, що велике значення для визначення сутності філософії освіти має з'ясування того, чим відрізняється «освічена людина» від «людини знаючої і компетентної», і що таке «людина культурна» - складний результат духовного розвитку чи просто «освічена або навчена» (Kremenj, 2014, p. 482-483).

Це додатково актуалізує аналіз основних змін у сфері освіти в контексті глибинних процесів, зумовлених цивілізаційними змінами, а саме переходом від індустріального до постіндустріального, інформаційного суспільства, яке стає значною мірою людиноцентристським, адже індивідуальний розвиток людини $\epsilon$ не лише показником прогресу, але й передумовою наступного розвитку суспільства. Оскільки освіта забезпечує індивідуальний розвиток людини, важливо трансформувати іï в контексті вимог і можливостей XXI ст.

\section{ЛІТЕРАТУРА}

1. Андрущенко В. Вийти за межі моделі «розвитку навздогін». Віче. 2001. № 10. С. 78-90.

2. Бойченко М. Цінності як категорія філософської освіти (соціальнофілософський та філософсько-антропологічний ракурси). Філософія освіти. 2009. № 1. С. 99-107.

3. Губернський Л. Сучасна освіта: філософські стратегії та пріоритети. Альманах. Філософські проблеми гуманітарних наук. 2012. № 21. С. 5-8.

4. Дьюи Д. Демократия и образование. Москва : Педагогика-Пресс, 2000. $384 \mathrm{c.}$

5. Клепко С. Філософія освіти в Європейському контексті. Полтава : ПОІППО, 2006. 338 с.

6. Кремень В. Креатив філософії освіти в синергії сучасного знання. Київ : Київський університет ім. Б. Грінченка, 2014. 469 с.

7. Култаєва М. Суспільне покликання філософії освіти у сучасних соціокультурних контекстах. Вісник Харківського національного педагогічного університету імені Г.С. Сковороди. Філософія. 2014. № 42. С. 186-194. 
8. Міщенко М. Філософія освіти: соціокультурний вимір. Гуманітарний вісник Запорізької державної інженерної академії. 2015. № 60. С. 278-286.

9. Молодиченко В. Модернізація цінностей в українському суспільстві засобами освіти (філософський аналіз). Київ : Знання України, 2010. 383 с.

10. Предборська І. Постнекласичні ін(тер)венції в освітньому дискурсі Вища освіта Украӥни. 2003. № 2. С. 37-40.

11. Радіонова I. Трансформації американської критичної педагогіки: евристичний потенціал і перспективи його застосування. Вісник Харківського національного педагогічного університету імені Г.С. Сковороди. Філософія. 2013. № 40. С. 192-203.

12. Glass R.D. Education and the Ethics of Democratic Citizenship. Studies in Philosophy and Education. 2000. № 19. P. 275-296.

13. Katz M. The Road to Nowhere Begins with There We Are Rethinking the Future of American Education. Interchange. 1996. № 27. P. 261-277.

14. Peters R.S. Ethics and Education. London : George Allen \& Unwin Ltd, $1968.319 \mathrm{p}$.

15. Peters R.S. The Logic of Education. London : Routledge \& Kegan Paul, 1972. $147 \mathrm{p}$.

\section{REFERENCES}

1. Andrushhenko, V. (2010) Vyjty za mezhi modeli «rozvytku navzdoghin» [Go through the edge of model "follow-up development"]. Viche - Assembly, 10, 78-90 [in Ukrainian]

2. Bojchenko, M. (2009). Cinnosti jak kateghorija filosofsjkoji osvity (socialjno-filosofsjkyj ta filosofsjko-antropologhichnyj rakursy) [Values as a category of educational philosophy (social-phylosophic and philosophicalanthropologycal foreshortenings]. Filosofija osvity - Phylosophy of education, 1, 99-107 [in Ukrainian].

3. Ghubernsjkyj, L. (2012). Suchasna osvita: filosofsjki strateghiji ta priorytety [Modern education: philosophical strategies and priorities Aljmanakh. Filosofsjki problemy ghumanitarnykh nauk - Almanac. Phylosophical problems of humanitarian sciences, 2, 5-8 [in Ukrainian].

4. Djjuy, D. (2000) Demokratyja y obrazovanye [Democracy and education]. Moscow.: Pedaghoghyka-Press. 384 p. [in Russian].

5. Klepko, S. (2006) Filosofija osvity v Jevropejsjkomu konteksti [Phylosophy of education in European context]. Poltava: POIPPO. 338 p. [in Ukrainian].

6. Kremenj, V. (2014) Kreatyv filosofiji osvity v synerghiji suchasnogho znannja [Creativity of educational philosophy in synergy of modern knowledge]. Kyiv: Kyivskyi universytet im. B. Ghrinchenka [in Ukrainian].

7. Kultajeva, M. (2014) Suspiljne poklykannja filosofiji osvity u suchasnykh sociokuljturnykh kontekstakh. [Public calling of educational philosophy in modern social and cultural contexts]. Visnyk Kharkivsjkogho nacionaljnogho 
pedaghoghichnogho universytetu imeni Gh. S. Skovorody. Filosofija. Phylosophy, 42, 186-194.

8. Mishhenko, M. (2015) Filosofija osvity: sociokuljturnyj vymir [Phylosophy of education: Social and cultural dimension]. Ghumanitarnyj visnyk Zaporizjkoji derzhavnoji inzhenernoji akademiji - Humanitarian sciences, 60, 278-286.

9. Molodychenko, V. (2010) Modernizacija cinnostej v ukrajinsjkomu suspiljstvi zasobamy osvity (filosofsjkyj analiz) [Modernization of values in Ukrainian society by the methods of education (philosophical analysis)]. Kyiv : Znannja Ukrajiny. [in Ukrainian].

10. Predborsjka, I. (2003) Postneklasychni in(ter)venciji v osvitnjomu dyskursi [Postnoclassical in(ter)ventions in educational discourse]. Vyshha osvita Ukrajiny - Higher education of Ukraine, 2, 37-40.

11. Radionova, I. (2013) Transformaciji amerykansjkoji krytychnoji pedaghoghiky: evrystychnyj potencial i perspektyvy jogho zastosuvannja. [Transformation of American critical pedagogy: heuristic potential and perspectives]. Visnyk Kharkivsjkogho nacionaljnogho pedaghoghichnogho universytetu imeni Gh. S. Skovorody. Filosofija. - Phylosophy, 40, 192-203.

12. Glass R. D. Education and the Ethics of Democratic Citizenship. Studies in Philosophy and Education. 2000. № 19. P. 275-296.

13. Katz M. The Road to Nowhere Begins with There We Are Rethinking the Future of American Education. Interchange. 1996. № 27. P. 261-277.

14. Peters R.S. Ethics and Education. London: George Allen \& Unwin Ltd, 1968. $319 \mathrm{c}$.

15. Peters R.S. The Logic of Education. London: Routledge \& Kegan Paul, 1972. $147 \mathrm{c}$.

Стаття надійшла до редакиії 25.03.21 